\title{
Constraining a density-dependent flow model with the transient electromagnetic method in a coastal aquifer in Mexico to assess seawater intrusion
}

\author{
Juan Antonio Torres-Martinez ${ }^{1}$ - Abrahan Mora ${ }^{1}$ - José Alfredo Ramos-Leal ${ }^{2}$ - Janete Morán-Ramírez ${ }^{2}$. \\ Claudia Arango-Galván ${ }^{3}$. Jürgen Mahlknecht ${ }^{1}$
}

Received: 8 December 2018 / Accepted: 29 July 2019 / Published online: 23 August 2019

(C) The Author(s) 2019

\begin{abstract}
Saltwater intrusion is one of the most pressing environmental concerns in coastal areas with increased water demands. Water extraction decreases the level of fresh groundwater, reducing the water pressure and allowing saltwater to flow further inland. Tools for simulating, monitoring and managing saltwater intrusion can provide valuable support in decision-making for management options. In this work, such a tool was developed for the arid coastal aquifer of La Paz in Baja California, Mexico. A geomodel was generated by using a transient electromagnetic method (aquifer geometry, saltwater intrusion). This geomodel, in turn, was used to construct a three-dimensional density-dependent flow model to simulate groundwater flow and saltwater intrusion during the past decades. The results confirmed that a large cone of depression had formed due to excessive pumping in the agricultural area. This successively led to the inversion of the hydraulic gradient and seawater intrusion advancement on the order of 6-8 km inland in the northern-central portion of the aquifer. Freshwater recharge mostly originates from the mountainous southeastern portion of the basin. It supplies water for the city of La Paz and counteracts the saltwater intrusion advancement. The alternation of advancement and retreat of the freshwater-saltwater interface could be attributed to changing climate effects and/or policy changes.
\end{abstract}

Keywords Coastal aquifers $\cdot$ Seawater intrusion $\cdot$ Transient electromagnetics $\cdot$ Groundwater flow modeling $\cdot$ Mexico

\section{Introduction}

Groundwater has been considered the most important freshwater resource for drinking and irrigation in coastal regions with an arid or semiarid climate. However, low recharge rates induced by low rainfall values and/or overexploitation of groundwater in these regions can modify the natural flow system, inducing the flow of seawater inland from the

Jürgen Mahlknecht

jurgen@tec.mx

1 Escuela de Ingeniería y Ciencias, Tecnológico de Monterrey, Eugenio Garza Sada 2501, 64849 Monterrey, Mexico

2 División de Geociencias Aplicadas, Instituto Potosino de Investigación Científica y, Tecnológica, Camino a la Presa de San José 2055, Lomas 4ta Secc, 78216 San Luis Potosí, Mexico

3 Instituto de Geofísica, Universidad Nacional Autónoma de México, Ciudad Universitaria, Delegación Coyoacán, 04510 México, CDMX, Mexico coastline (seawater intrusion; Alfarrah and Walraevens 2018; Zarif et al. 2018).

Effective tools are of vital importance for studying coastal aquifers with seawater intrusion problems. Proper management requires good knowledge of the aquifer system and the ability to simulate present groundwater conditions and forecast its future behavior under different scenarios of natural forcing and human interactions (Kourgialas et al. 2016; De Filippis et al. 2016). Therefore, the use of groundwater flow models for modeling seawater intrusion has been increasing globally in recent years, given that seawater intrusion has become one of the principal causes of groundwater quality deterioration in coastal aquifers stressed by urban growth and anthropogenic activities (Hugman et al. 2015; Comte et al. 2017; Siaka et al. 2017; Gopinath et al. 2018).

When modelers try to simulate groundwater flow in heterogeneous aquifer systems, they typically face difficulties due to a lack of information regarding the system's parameters, hydraulic characteristics and their distribution. Thus, geophysical methods can provide information to fill this gap, 
determining the geometrical features of different geohydrological targets showing a broad and complex geological heterogeneity (Kourgialas et al. 2016; Meyer et al. 2019). Techniques such as electrical resistivity tomography, electromagnetic induction, airborne electromagnetic survey and selfpotential, among others, are commonly used geophysical methods for mapping near-surface geology and for identifying and modeling saline intrusion in near-surface aquifers (Francés et al. 2015; Kazakis et al. 2016; Graham et al. 2018; Meyer et al. 2019). However, the transient electromagnetic method (TEM) has become one of the leading noninvasive methods for imaging alluvial aquifers in coastal areas because of its high cost-effectivity and excellent resolution (Tezkan 1999; Danielsen et al. 2003; Francés et al. 2015). Constant developments of novel schemes for processing of the acquired TEM data can provide geologically (realistic interpretive model) two- and three-dimensional (2D and 3D) resistivity models without much reliance on the availability of a priori subsurface information (Soupios et al. 2010; Kalisperi et al. 2018). However, although the TEM method has been fully used for delineating saline intrusion zones (Ziadi et al. 2017; Kalisperi et al. 2018), only a few efforts exist to combine the geophysical data obtained through TEM measurements with 3D density-dependent flow modeling to reproduce the movement of the freshwater-seawater interface in coastal aquifers stressed by excessive groundwater abstraction (Soupios et al. 2015; Kourgialas et al. 2016).

Given its geographical conditions, Mexico has a vast variety of climates ranging from warm-humid climates in the southeast of the country to desert or semidesert environments in the north, which leads to different patterns in the management of water resources. The peninsula of Baja California, located in northwestern Mexico, has two of the most famous tourist destinations in the region, Los Cabos and La Paz, the latter being capital of the state of Baja California Sur and very well known as a focal point of commerce and ecotourism (de los Monteros López-Espinosa 2002). In fact, the constant growth of tourism (more than 320,000 visitors per year) in this arid climate location (INEGI 2017) has increased the stress over the exploited aquifer and has forced officials to rethink the future of the city based on the provision of water resources.

Owing to its location $(60 \mathrm{~km}$ north of the Tropic of Cancer), La Paz has a prevailing coastal desert climate. The water supply system of this city depends entirely on the underlying aquifer system, which shows a water balance deficit as a result of long-term water overextraction following water use permits whose volumes exceed the availability of renewable water resources. Water overextraction has occurred during the last five decades despite a decree of closure emitted by the national water authority (Comisión Nacional del Agua, CONAGUA) enacted in 1954 (CNA 2002). Water overdraft has brought consequences such as spring drought, continuous drawdown of water levels $\left(0.5-1 \mathrm{~m} \mathrm{year}^{-1}\right)$, increase in pumping costs, and the deterioration of groundwater quality due to seawater intrusion (Tamez-Meléndez et al. 2016; Torres-Martínez et al. 2017; Cruz Falcón et al. 2017).

Recent hydrogeochemical and isotopic tools applied in La Paz aquifer revealed that $35 \%$ of the abstracted wells had been affected by seawater intrusion because the aquifer is recharged in part by seawater flow in the lower plain portion of the La Paz Valley (Mahlknecht et al. 2017). The growing population, tourism and agricultural activities can only exacerbate this situation in the years to come; thus, management of seawater intrusion must be put in place in the La Paz area. For this, it is necessary to understand how the aquifer works and evaluate the impacts that well pumping exerts on groundwater resources. To our knowledge, only two previous works performed in insular environments have used TEM data to constrain densitydependent flow models (Soupios et al. 2015; Kourgialas et al. 2016). Therefore, given that the TEM method is a fully geophysical technique used for assessing the geological background and salinity gradients in alluvial aquifers such as La Paz aquifer, a 3D density-dependent flow model is proposed based on TEM data to obtain an adequate representation of the La Paz aquifer system and evaluate the behavior of the freshwater-seawater interface under the current groundwater extraction conditions.

Overall, the present study aimed at assessing, for the first time in a continental environment, the hydrodynamics of an overexploited alluvial aquifer impacted by seawater intrusion using an approach which constrains a density-dependent flow model with geoelectrical resistivity information. Specifically, a comprehensive geophysical data model of the study areacompatible with previous hydrogeological and geological information of the study area- was created first, and then a 3D density-dependent groundwater flow model was constructed based on the geomodel of the aquifer system.

\section{Study area and hydrogeological setting}

The city of La Paz is located to the south of the state of Baja California Sur, towards the western coast of the Gulf of California (Fig. 1). The climate in this area is warm-dry over the year, with an average annual temperature of $22.5^{\circ} \mathrm{C}$ an and annual total precipitation of $263 \mathrm{~mm}$ (CONAGUA 2010). The rainfall is mainly associated with tropical storms or hurricanes, which occur between July and October. More than $75 \%$ of the total annual precipitation is originated in this way (CONAGUA 2010), and, given the climatic conditions, largely become evaporated.

Surface waters are ephemeral and thus not used for water supply. All water is provided by 155 production wells located mainly in the central and southwestern parts of the aquifer. The 


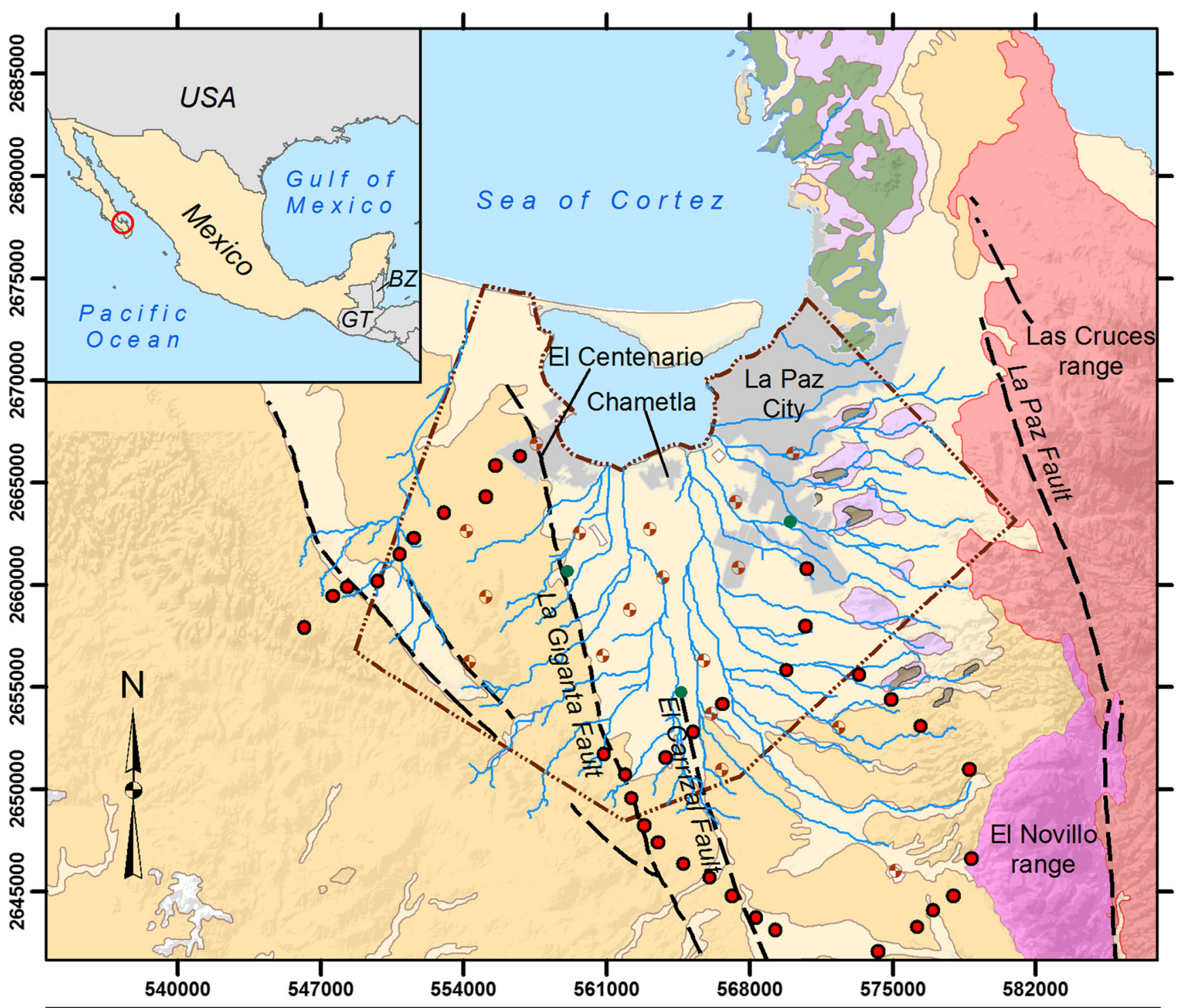

\section{Legend}

\begin{tabular}{|c|c|c|c|c|c|}
\hline i........ & Model domain & $\bullet$ & Exploratory borehole & Geology & Volcanoclastic rock \\
\hline & Urban areas & $\theta$ & TEM sounding (2001) & Alluvium sediments & Acid tuff \\
\hline$\longrightarrow$ & Ephemeral rivers & 0 & TEM sounding (2016) & Sandstone & Gabbro \\
\hline-- & Fault & $\begin{array}{l}\mathrm{GT} \\
\mathrm{BZ}\end{array}$ & $\begin{array}{l}\text { Guatemala } \\
\text { Belize }\end{array}$ & Rhyolite & Granite \\
\hline
\end{tabular}

Fig. 1 Location of the La Paz aquifer, Baja California Sur, Mexico. Geology map of the study area with the fault system (modified from Torres-Martínez et al. 2017), and location of the model area and transient electromagnetic method (TEM) data coverage area. Coordinate system: WGS 84/UTM Zone $12 \mathrm{~N}$ groundwater extracted is approximately 32 million $\mathrm{m}^{3}$ year $^{-1}$, which is used for water supply (68\%: 21.8 million $\mathrm{m}^{3}$ year $^{-1}$ ),

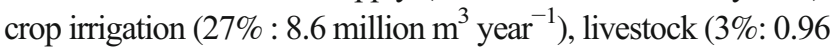
million $\mathrm{m}^{3}$ year $\left.{ }^{-1}\right)$ and other services, including industry ( $2 \%$ : 0.64 million $\mathrm{m}^{3}$ year $^{-1}$ ). The depth of the production wells varies from 7 to $200 \mathrm{~m}$ (Monzalvo 2010). The aquifer, being coastal, interacts with seawater from the Sea of Cortez (Gulf of California), and because of its strong overextraction, the aquifer is classified by authorities as overexploited with evidence of seawater intrusion (CNA 2002).

Physiographically, the La Paz area is composed of three large structures: a coastal plain (valley), plateaus 
and mountain ranges that reach $900 \mathrm{~m}$ above sea level (m asl). The geological base of the area is a metamorphic complex, consisting of Mesozoic shales, phyllites, sillimanite, and gneiss. This unit is overlain by intrusive Cretaceous rocks, namely, gabbro, granite, and granodiorite, emerging in the eastern portion of the study area (Las Cruces mountain range). Miocene sandstones, conglomerates and fractured volcanic rocks (Comondú Formation, San Ignacio Formation, and San Isidro Formation) crop out in the western portion of the study area. In the centralnorthern part, the valley comprises unconsolidated alluvial deposits such as sands, silts, and clays. From a structural point of view, La Paz Valley corresponds to a graben, delimited by two major faults (La Paz and La Giganta) with N-S orientations (Hausback 1984; Cruz-Falcón 2007; Monzalvo 2010; McCloskey et al. 2015). Figure 1 shows a geologic map of La Paz indicating the locations of the major faults.

The hydrostratigraphy of the valley includes an uppermost unit that corresponds to nonconsolidated, granular sediments and volcanoclastic material with little compaction and medium-to-high permeability. The underlying second unit matches the volcanic flows of the Comondú Formation, with high hydraulic conductivity as a result of fracturing, but is only of local importance due to its discontinuity. These two units represent an unconfined aquifer system approximately $300-400 \mathrm{~m}$ thick and having an average hydraulic conductivity of $1.2-14.3 \times 10^{-3} \mathrm{~m} \mathrm{~s}^{-1}$. Finally, the deeper third unit corresponds to the PreTertiary intrusive rock formations that outcrop in the Cordillera Oriental portion of the study area and have low permeability. The basement of these units is located approximately $900 \mathrm{~m}$ below land surface and consists of a metamorphic complex (CIGSA 2001).

Stable and radiogenic isotope studies performed previously on the La Paz aquifer have identified five different groundwater recharge sources (Tamez-Meléndez et al. 2016; Mahlknecht et al. 2017). The most important recharge source originates naturally in the eastern and southeastern mountainous portion of the study area. This groundwater is from meteoric origin and flows from southeast to the northwest. Other recharge sources identified using chlorofluorocarbons and stable isotopes were irrigation return flow along the agricultural lands located in the central part of the study area, groundwater recharge from seawater intrusion and some recharge from anthropogenic sources in urbanized areas, which can be derived by water leaks from the obsolete urban water supply system. Finally, radiocarbon data identified a local coning of deeper groundwater flow consisting of warm water of up to 4,700 years. This regional flow was located in the western portion of the study area and was suggested as an interconnection between the upper aquifer and the lower aquifer units.

\section{Methodology}

\section{Geophysical method}

Electrical resistivity is affected by many parameters, i.e., mostly water content, permeability, composition, temperature, pressure and salinity; thus, electric and electromagnetic methods are widely used to obtain a better insight into aquifer systems. The transient electromagnetic method is typically used to infer the subsurface electrical resistivity distribution at relatively shallow depths (i.e., less than $1 \mathrm{~km}$ ). A stable current is circulated through a cable loop (transmitter). When the current is abruptly interrupted, a magnetic field is induced, which is damped and disappears quickly. The rapid variation in the magnetic field generates eddy currents into the subsurface that responds to different electrical properties at different depths, and its temporal evolution can be measured by a receiver, usually using the same primary circuit that originated the magnetic field (a cable coil) or another device (e.g. induction magnetometer). The process is repeated several times, applying a stacking process to generate a single mean curve showing the evolution of the induced potentials as a function of time. Finally, this master curve is inverted to establish the geoelectrical model (i.e., true resistivity values at different depths) that fits the subsurface response.

In the La Paz area, a TEM survey was carried out using Sirotem-S equipment, with a single loop configuration (i.e., the same coil was used as transmitter and receiver) with dimensions of $150 \mathrm{~m} \times 150 \mathrm{~m}$, reaching a maximum interpretation depth of $500 \mathrm{~m}$. In total, 50 soundings were acquired, measuring eight curves per location across the study area and complemented with 20 TEM soundings measured during a previous survey (CIGSA 2001). The TEM data were inverted to a $1 \mathrm{D}$ model employing an Occam regression, fitting the model responses with a root mean square error (RMSE) of less than 5\%. Regarding the depth resolution, it was performed following the proposal by Flores et al. (2013) in order to assure the reliability of the models at depth. The subsurface electrical resistivity distribution was inferred by interpolating the information provided by all the 1D models at different depths using a Kriging scheme. Nevertheless, all the interpretation of the geoelectrical images was performed using only the covered area by the TEM soundings. Geoelectrical anomalies that were not supported by at least two or more soundings were ignored.

\section{Flow modeling}

Based on the geophysical interpretation, the hydrogeological units were identified, and the geometry of the 3D geomodel was built. In aquifers with seawater intrusion problems, a variable-density groundwater flow may be simulated by a dispersive solute-transport approach. In such an approach, fluid 
density can vary continuously from cell to cell in a model domain (De Filippis et al. 2016). Thus, the finite element density-dependent subsurface flow code FEFLOW (Diersch 2014) was used for modeling the coastal aquifer of $\mathrm{La} \mathrm{Paz}$ under the assumption that: (1) the porous medium is considered rigid and incompressible (Boussinesq approximation), (2) fluid motion can be described by Darcy's law, and (3) dispersion follows the Fickian dispersion law (Diersch 1988; Kourgialas et al. 2016).

Groundwater movement through porous materials of constant density in transient can be described in three dimensions using the general groundwater-flow equation, which is based on Darcy's law (Eq. 1):

$\nabla(k \nabla h)+W(\mathrm{x}, \mathrm{y}, \mathrm{z})=S_{\mathrm{s}} \frac{\delta h}{\delta t}$

where $k$ is hydraulic conductivity $\left(\mathrm{LT}^{-1}\right), h$ is hydraulic head (L), $W$ is volumetric flux per volume unit (representing sources and/or sinks) in the coordinates $\mathrm{x}, \mathrm{y}$ (horizontal plane) and z (vertical), $S_{\mathrm{s}}$ is specific storage and $t$ is time (T) (Delleur 2016; Khayyun 2018). The generalized form of Darcy's law for variable-density fluid flow is derived as follows (Eq. 2):

$q=-k\left(\nabla h-\frac{\rho-\rho^{\mathrm{w}}}{\rho^{\mathrm{w}}} \frac{g}{|g|}\right)=-\frac{k}{\mu}(\nabla p-p g)$

where $\rho$ and $\rho^{\mathrm{w}}$ are the macroscopic mass density of the fluid and the mass density of water $\left(\mathrm{M} \mathrm{L}^{-3}\right)$, respectively, $\mathbf{g}$ is the vector of gravity acceleration $\left(\mathrm{L} \mathrm{T}^{-2}\right), p$ the dynamic pressure (P) and $\mu$ is the dynamic viscosity of the fluid ( $\mathrm{P} \mathrm{T}^{-1}$; Kolditz et al. 1998).

In the La Paz area, the model domain area covers an extension of approximately $475 \mathrm{~km}^{2}$ and a depth of $500 \mathrm{~m}$ below ground level. As a first approximation, the discretization in the horizontal plane consisted of finite triangular elements with refining zones of approximately $100 \mathrm{~m}$ around pumping wells, verifying the Delaunay criterion violations (Weatherill 1992; Rodríguez and Silveira 2017). The vertical discretization of the model area consisted of dividing the model area into four uniform hydrogeological layers (some of these units also have subunits due to the presence of water). The properties of the hydrogeological units were obtained, linking the resistivity maps with well log information from exploration wells and from geological sections defined in previous studies of the area (Hausback 1984; Aranda-Gómez and Pérez-Venzor 1988; SGM 1995; CIGSA 2001; Cruz-Falcón 2007). For the top elevation, a digital elevation model (DEM) with a pixel resolution of $15 \mathrm{~m} \times 15 \mathrm{~m}$ and an RMSE of $4.8 \mathrm{~m}$ was used (INEGI 2013). To improve the calibration in the north and south areas of the model domain, the mesh was refined. The final configuration resulted in 51,375 nodes and 80,972 elements (Fig. 2).
A first-type flow boundary (Dirichlet) was set along the coastline to the north of the study area (zone 1, Fig. 2). For the first layer, the boundary was set to zero, and for the rest of the layers, the boundary was set to the equivalent freshwater head assuming a seawater density of $1,025 \mathrm{~kg} \mathrm{~m}^{-3}$. Secondtype flow boundaries (Neumann) were set along lateral limits (zone 2, Fig. 2): in the eastern flank of the model due to the presence of relatively impermeable bedrock (mainly granite and gabbro) along a fault (La Paz fault) which creates a physical boundary condition (acting as a barrier) to the alluvial aquifer; in the western flank of the model, groundwater flows parallel to topographic lows which forms an intermittent streamline (Fig. 1) which, added to the lack of wells close the aquifer limit, serves as groundwater divides, forming a hydraulic no-flow boundary. A first-type flow boundary was set along the southern flanks of the study area where inflow is expected (zone 3), with initially estimated at $70 \%$ of the aquifer recharge (Cruz Falcón et al. 2013). All the 147 pumping wells were included in the model using well depths (7$201 \mathrm{~m})$, extraction rates $(0.3-50 \mathrm{~L} / \mathrm{s})$, and tube radius $(0.07-$ $0.17 \mathrm{~m}$ ). Table 1 shows the properties of the different hydrogeologic units used in the model domain such as the initial values for hydraulic conductivity, the specific storage, and the porosity.

Spatial variable recharge rates were assigned as the annual inflow parameter on the top layer of the model. The different recharge sources included the following: recharge by rainwater infiltration, irrigation return flow in agricultural lands, and leaks from the water system in urbanized areas. The recharge values from precipitation were obtained from an annual hydrological balance (Torres-Martínez 2017). The use of monthly recharge rates was discarded due to the availability of groundwater extractions only at the annual level—for example, for 1997 (Fig. 3), which was an average year, the recharge values varied from $14 \mathrm{~mm}$ in the valley floor to $46 \mathrm{~mm}$ in the mountain ranges. The annual recharge values were assigned by zones according to the different land uses and soil types in the study area, adding an extra recharge flux in the urban areas caused by water leaks from the obsolete urban water supply system, which has been estimated by the local authority at $31.8 \%$, on average, of the total water supplied to La Paz (SAPA 2015). The additional recharge flux assigned in the irrigated agriculture area was between 15 and $35 \%$ of the total water used for irrigation, according to the different crop type in areas with similar climatic characteristics. Groundwater inflow coming from the western flank of the aquifer was estimated according to values reported by Cruz Falcón et al. (2013), who estimated the horizontal inflows through pumping tests.

A two-stage calibration was performed. First, the flow model was calibrated for the steady-state mode by matching the hydraulic-heads calculated by the model to the measured groundwater levels of 42 wells, which belong to the monitoring network of CONAGUA. It is important to mention that 


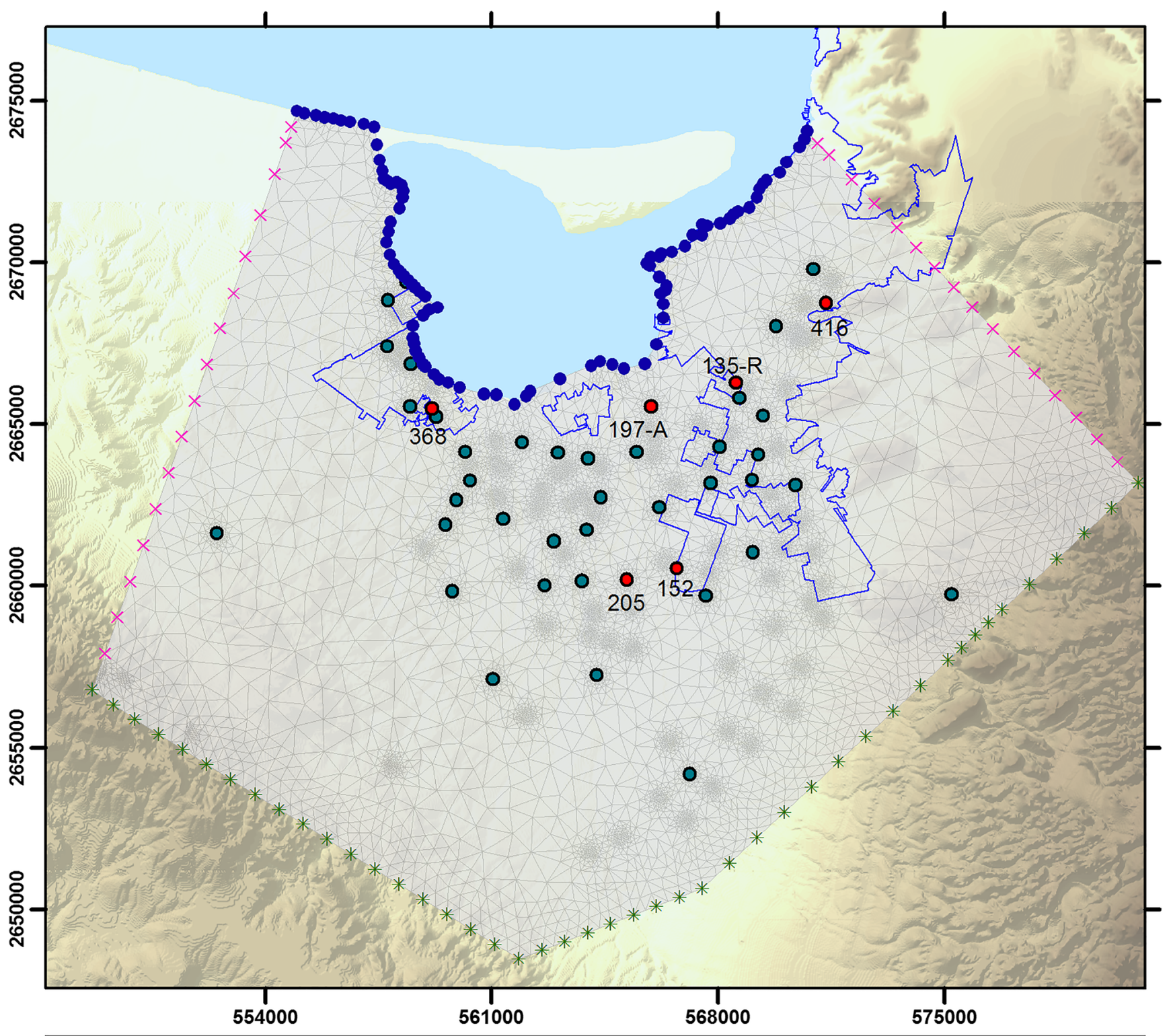

Legend

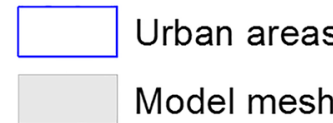

- Wells selected for temporal analysis

- Observed wells used for calibration
Boundary conditions

- Zone 1

$\times \quad$ Zone 2

* Zone 3

Fig. 2 Mesh density, boundary conditions, and selected observation wells in the domain area

water level measurements have been performed approximately once a year by CONAGUA using water level meters (manual method) and taking the reference level elevation derived from differential GPS surveys. Although there are temporal data about the hydraulic-heads in the majority of these wells, CONAGUA has not been used to perform a rigorous seasonal periodicity regarding these water-table measurements. Thus, the selected year for steady-state conditions was 1997 because it was the year with the most hydraulic head coverage data. The hydraulic conductivity and lateral influx rates in the south were used as calibration parameters for the flow model. Second, based on the outcomes of the first stage, the flow model was calibrated in transient-state mode considering 20 years (1990-2010), featuring an automatic time-step control scheme on behalf of the stability given to the model and natural convergence. 
Table 1 Initial values for three-dimensional hydraulic conductivity $\left(k_{\mathrm{x}}, k_{\mathrm{y}}, k_{\mathrm{z}}\right)$, specific storage $\left(S_{\mathrm{s}}\right)$, and porosity $(N)$ of the different hydrogeological units used in the model (adapted from Cruz-Falcón 2007; Monzalvo 2010)

\begin{tabular}{|c|c|c|c|c|c|c|}
\hline Units & Description & $k_{\mathrm{x}}\left(1 \times 10^{-4} \mathrm{~m} \mathrm{~s}^{-1}\right)$ & $k_{\mathrm{y}}\left(1 \times 10^{-4} \mathrm{~m} \mathrm{~s}^{-1}\right)$ & $k_{\mathrm{z}}\left(1 \times 10^{-4} \mathrm{~m} \mathrm{~s}^{-1}\right)$ & $S_{\mathrm{s}}\left(1 \times 10^{-4} \mathrm{~L} \mathrm{~m}^{-1}\right)$ & $N$ \\
\hline Layer 1 & Alluvial material (sand, gravel) & 1.0 & 1.0 & 0.1 & 3.5 & 0.37 \\
\hline Layer 2 & $\begin{array}{l}\text { Comondú and San Ignacio formation } \\
\text { (calc-alkaline rocks) }\end{array}$ & 0.15 & 0.15 & 0.015 & 7.5 & 0.15 \\
\hline Layer 3 & $\begin{array}{l}\text { San Isidro formation (rhyolites, breccia, andesites, } \\
\text { intercalated with conglomerates and sandstones) }\end{array}$ & 0.031 & 0.031 & 0.0031 & 2.85 & 0.20 \\
\hline Layer 4 & $\begin{array}{l}\text { Tepetate formation (marine sediments: } \\
\text { sandstone and lutite) }\end{array}$ & 0.019 & 0.019 & 0.0019 & 4.35 & 0.10 \\
\hline
\end{tabular}

For the purpose of evaluating the effectiveness of the model, a qualitative and quantitative assessment was performed. The qualitative assessment (calibration process) consisted of comparing measured versus simulated hydraulic heads of wells to identify outliers and bias of the model by comparing it graphically against a 1:1 line (Piñeiro et al. 2008); furthermore, time series allow us to identify where the model is more accurate (Vaze et al. 2011). Once the hydraulic heads were adjusted from the steady-state simulation, a quantitative assessment was carried out comparing measured versus calculated hydraulic-heads using statistical techniques such as the coefficient of correlation $\left(r^{2}\right)$, the
RMSE and the Nash-Sutcliffe Goodness of fit (NSE-GOF; Eq. 3), which are useful for describing the degree of collinearity between simulated and observed values $\left(r^{2}\right)$, identifying the error measured in the units of interest (RMSE), and evaluating the prediction of the model (NSE-GOF; Moriasi et al. 2007; Ritter and Muñoz-Carpena 2013; Chai and Draxler 2014). The term SD in Eq. (3) denotes the standard deviation of the observed values.

$\mathrm{NSE}-\mathrm{GOF}=1-\left[\frac{1}{\left(\frac{\mathrm{SD}}{\mathrm{RMSE}}-1\right)+1}\right]^{2}$

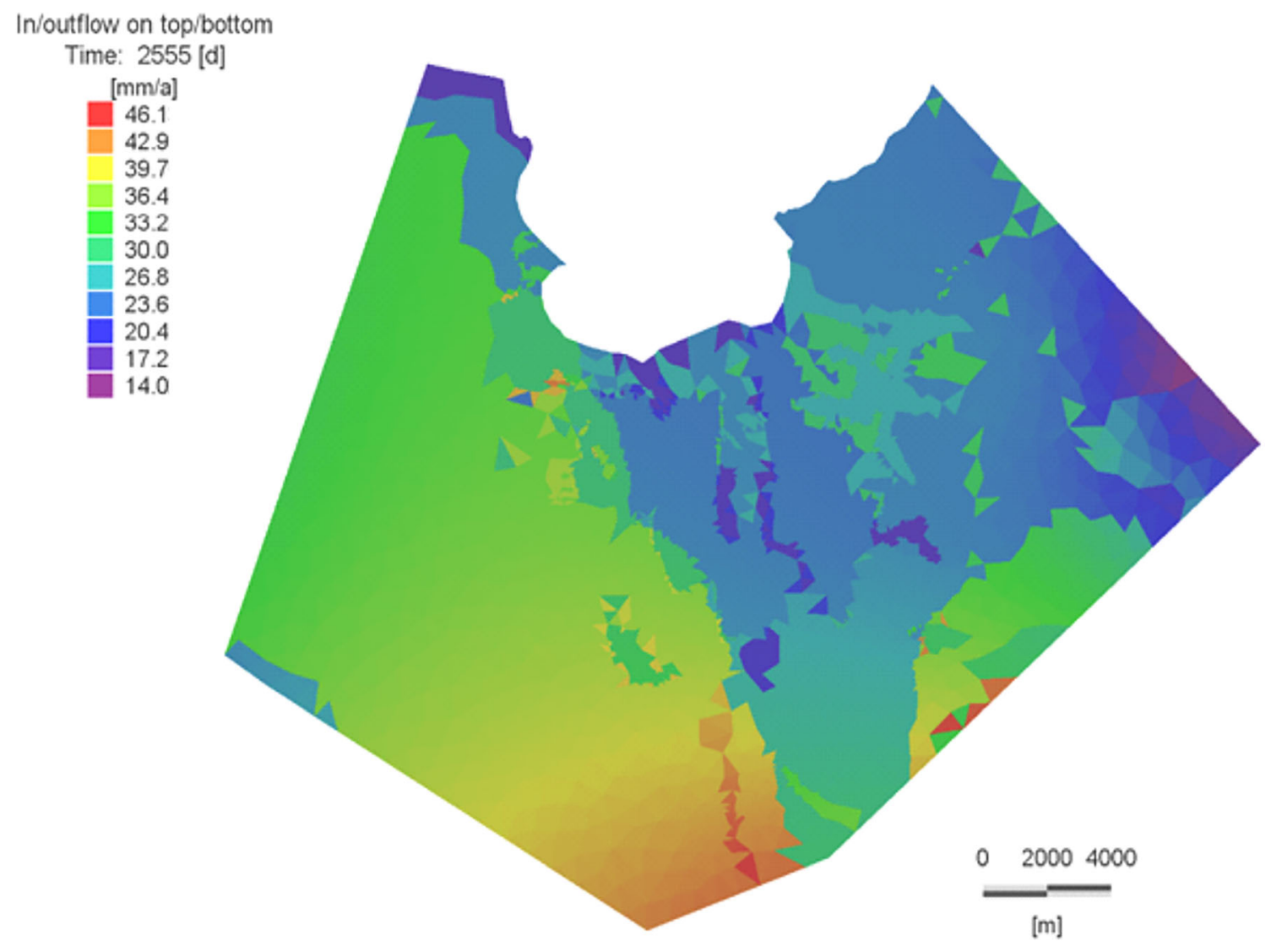

Fig. 3 Spatial distribution of annual water recharge by zones in 1997 


\section{Results and discussion}

\section{Geoelectrical survey results and contribution to the flow model setup}

The inverted TEM soundings (1D models) were interpolated to generate resistivity slices at different depths, providing total spatial coverage of the subsurface electrical distribution over the aquifer exploitation area. The resistivity maps were used to correlate the original geological model, including the fault system (Table 2), as well as to delineate the seawater intrusion.

As an example, Fig. 4 shows the cross-section $\mathrm{A}-\mathrm{A}^{\prime}$ where nine TEM soundings were interpolated to generate a pseudo 2D model. This cross-section reaches approximately $500 \mathrm{~m}$ deep and $22 \mathrm{~km}$ inland in the NW-SE direction starting from the coastline (A-A' location is shown in Fig. 5). The shallowest layer shows a lateral variation with resistivity values ranging from 5 to $20 \Omega \mathrm{m}$ in the northwestern portion and more than $20 \Omega \mathrm{m}$ in the opposite site of the profile. This behavior could be associated with recent sediments (Unit U1a). Additionally, the lower resistivities measured in these materials may suggest intrusion of the seawater in unit U2 inland (red arrow). Another subunit has been defined as $\mathrm{U} 1 \mathrm{~b}$, related to sands and altered rocks with resistivities ranging from 15 to $50 \Omega \mathrm{m}$. Underlying these horizons, unit U3 is defined as a low-medium resistivity layer that is most likely associated with sands and rhyolitic boles in a clay matrix of low permeability. This unit is probably responsible for preventing the inland advance of seawater in unit $\mathrm{U} 2$. Underneath this layer, subunit U4a is found in the southern portion, mainly composed of sandy-clayey materials with resistivity values less than $15 \Omega \mathrm{m}$. Although groundwater is currently extracted from subunit U1b (the maximum depth of the wells in this subunit is approximately $200 \mathrm{~m}$ ), subunit U4a may be considered a potential groundwater source. A different horizon (U4b) is found below $300 \mathrm{~m}$ depth, showing resistivities ranging from 15 to $35 \Omega \mathrm{m}$, most likely associated with sandy-clayey materials. Finally, in the southeastern portion of the profile, the granitic intrusive basement is observed as a high resistivity anomaly with values greater than $100 \Omega \mathrm{m}$.

On the horizontal slices, the low-resistivity zone (subunit U1a) is found in the northern area along La Paz Bay. This conductive zone extends to a depth of approximately $75 \mathrm{~m}$ (Fig. 5) and most likely indicates the presence of brackish water as a result of seawater intrusion into the sandy material and altered rocks. Between depths of 100 and $200 \mathrm{~m}$, unit U3 is predominant in the central region of the area and can be associated with agglomerates and sandy materials; however, in the southern region, low permeability sands and igneous rocks are inferred (Fig. 5). Below this horizon, between 200 to $300 \mathrm{~m}$, there is a layer characterized by the presence of brackish water in the northern portion and clayey matrix rocks in the middle of the valley. Nevertheless, at the bottom of this horizon (between 250 and $300 \mathrm{~m}$ ), a sandy-clayey layer appears and extends from the center to the SW. The deepest layer reached by the geoelectrical study $(400-500 \mathrm{~m})$ suggests the presence of granitic igneous rocks, which are considered the basement of the aquifer. The results of the horizontal depth slices were compared with borehole information and were used as an input for groundwater flow modeling.

Figure 5 clearly shows the influence of the saline intrusion in the northern portion of the La Paz aquifer in Baja California $(<10 \Omega \mathrm{m})$. It is possible that other structures are buried by the volcanic breccia to the NW of the study area, in such a way that the marine intrusion can extend to the SW of the coastline. At greater depths, the media becomes more resistive, whereby the influence of the marine intrusion only developed in the shallower units. Figure 5 also shows high-resistivity values in the shallower layers that cover most of the study area, and could be associated with the low water content in the volcanic rock.

According to the geoelectric study, the system works as an unconfined aquifer consisting of granular materials (gravels and sands) in the groundwater exploitation area, which is underlain by a semiconfined aquifer formed by a layer of fractured volcanic rock. Finally, the basement is identified as granitic intrusive and compact metamorphic complexes;
Table 2 Correlation between geoelectrical units and the lithological composition in the study area

\begin{tabular}{|c|c|c|}
\hline $\begin{array}{l}\text { Geoelectric } \\
\text { unit }\end{array}$ & $\begin{array}{l}\text { Resistivity range } \\
{[\Omega \mathrm{m}]}\end{array}$ & Lithological composition \\
\hline U1a & Less than 12 & $\begin{array}{l}\text { Saturated fine-to-medium granular materials, probably influenced by } \\
\text { seawater intrusion or brine }\end{array}$ \\
\hline U1b & More than 12 & Soil, dry sands and altered rock \\
\hline $\mathrm{U} 2$ & $1-15$ & $\begin{array}{l}\text { Saturated fine-to-medium granular materials, possibly with brackish wa- } \\
\text { ter }\end{array}$ \\
\hline $\mathrm{U} 3$ & $10-50$ & $\begin{array}{l}\text { Thick materials (agglomerates, sands and rhyolitic boles) in low } \\
\text { permeability clay matrix }\end{array}$ \\
\hline $\mathrm{U} 4 \mathrm{a}$ & $1-12$ & Saturated sandy-clayey materials and saturated sandy-clayey tuffs \\
\hline $\mathrm{U} 4 \mathrm{~b}$ & $12-30$ & Sandy materials and rhyolitic boles \\
\hline U5 & More than 20 & Low permeability igneous rocks (granitic composition) \\
\hline
\end{tabular}




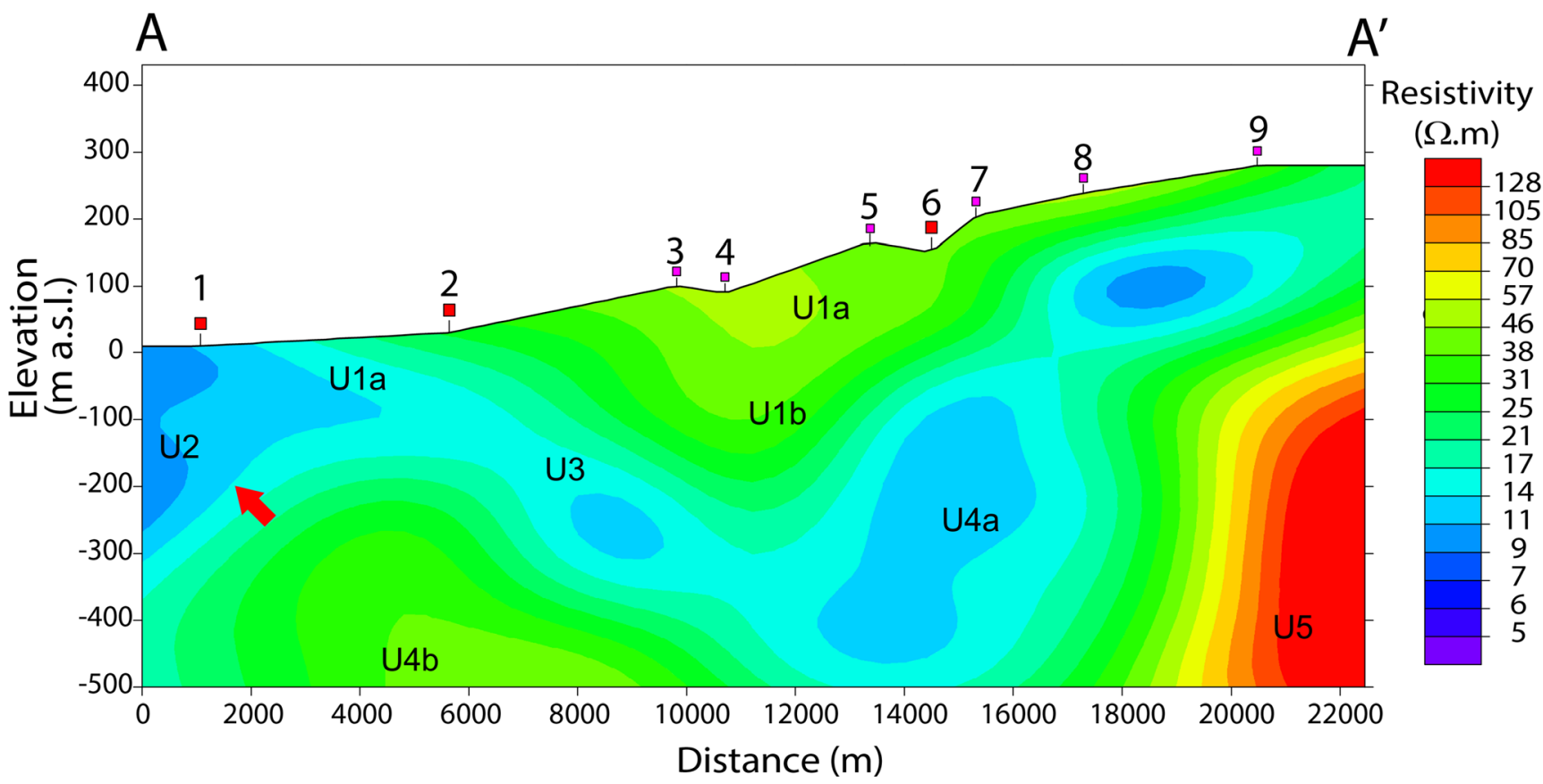

Fig. 4 Resistivity cross-section A-A' showing the different geoelectric units (the location of the profile is shown in Fig. 5)

furthermore, these two aquifers (the shallow overexploited aquifer and the deeper unexploited aquifer) have variable depths. The first aquifer is quite horizontally homogenous reaching almost $200 \mathrm{~m}$ of thickness, while the second aquifer varies from 200 to $400 \mathrm{~m}$ depth, which is in agreement with the results from previous studies (e.g. Cruz-Falcón et al. 2010).

\section{Density-dependent flow modeling}

Calibration of the flow model was developed in two phases. In the first stage, flow model calibration under steady-state conditions was performed using the hydraulic head values of 42 observation wells across the domain area recorded by CONAGUA in 1997 (Fig. 3). Once the results were obtained, the performance of the model was evaluated first by a visual inspection through a scatter plot graph between observed and simulated head values looking for an adjustment close to the 1:1 line (Fig. 6), which helped to identify the presence of outliers or bias in the model (Moriasi et al. 2007; Ritter and MuñozCarpena 2013). Following this evaluation, a statistical assessment was completed, obtaining a good fit reflected in the values of $r^{2}=0.96$, RMSE $=8.11 \mathrm{~m}$, and NSE-GOF $=0.99$. Accordingly, the groundwater flow model can be considered a model that successfully reproduces steady-state conditions.

The second-stage calibration of the flow model consisted of calibrating the model in the transient-state mode, in which an annual variability flow boundary condition was considered in the southern model boundary. In this step, the number of wells used was reduced from 42 to 20 due to a lack of information over the period. The results obtained for this calibration showed a lower percentage of adjustment in comparison with the steady-state condition $\left(r^{2}=0.85, \mathrm{RMSE}=3.53 \mathrm{~m}\right.$, NSE-GOF $=0.75$ ); however, these numbers can be considered satisfactory adjustment values. With this estimation achieved, it is possible to simulate and infer the tendency of the groundwater level fluctuations for each well and, therefore, the model can be further used for forecasting, taking into account the respective uncertainty analysis, which can be computed using different techniques such as null-space Monte Carlo method and linear uncertainty analysis, among others (Herckenrath et al. 2011; Sepúlveda and Doherty 2015).

Figure 7 depicts the observed versus simulated groundwater levels for six selected wells in different zones (urban, agricultural, and coastal zones) along the study area. Overall, almost all the wells located in the urban zone of $\mathrm{La} \mathrm{Paz}$ showed a small water-table rise between 2000 and 2010. In fact, well 416 (located in the eastern part of the city) showed the largest water-table rise during this period, increasing from 1.7 to $10.0 \mathrm{~m}$ asl. Previous work indicated that the chemistry of the groundwater in the urban zone is similar to that of the groundwater in the recharge areas of El Novillo and Las Cruces ranges (Tamez-Meléndez et al. 2016). In addition, the city of La Paz is supplied by groundwater taken from wells located in those recharge zones, which confirms that the increase in the water table in the urbanized zone is due to the infiltration from leaks of the obsolete water supply system, which was estimated on the order of 6.9 million $\mathrm{m}^{3}$ year $^{-1}$. On the other hand, the wells located in the agricultural zone showed a general downward trend in the water table from 

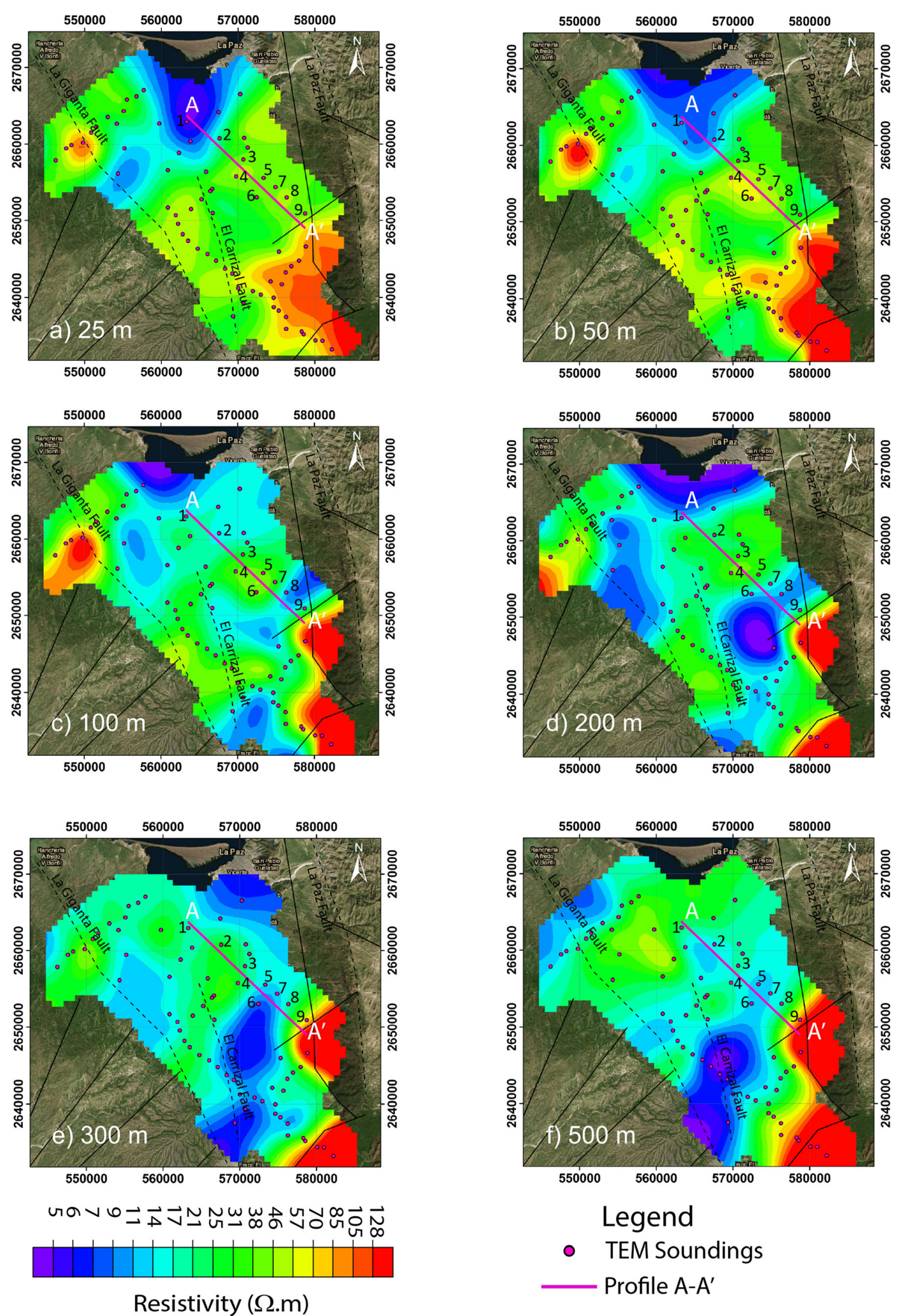

Fig. 5 a-f Horizontal depth slices of electrical resistivity generated at depths of 25, 50, 100, 200, 300, and $500 \mathrm{~m}$ 
Fig. 6 Simulated versus observed hydraulic head values under steady-state conditions

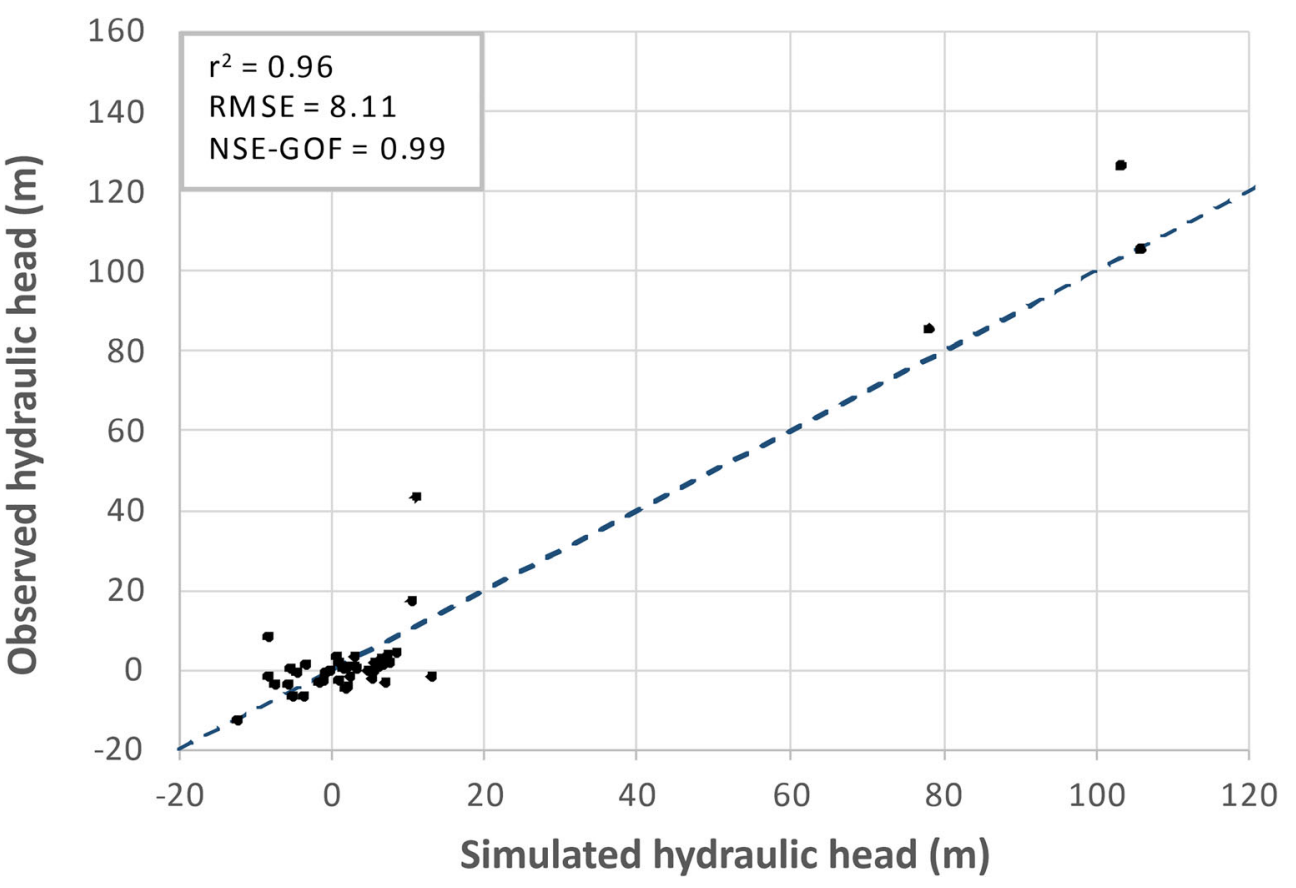

2000 to 2010 (the water table values of wells 152 and 205 are examples of this trend), with groundwater levels between 2 and $8 \mathrm{~m}$ below sea level ( $\mathrm{m} \mathrm{bsl}$ ) on average. However, the wells located close to the coastline showed no significant temporal changes in the water table (probably due to seawater recharge), with levels that varied between $3.0 \mathrm{~m}$ asl and $1.6 \mathrm{~m}$ bsl (wells 368 and 197-A, Fig. 7).

Figure 8 a illustrates the hydraulic head contours in slice 1 (50 $\mathrm{m}$ depth), which shows the zero head extending from the coastline to the east-central portion of the valley, approximately in the area between the city of La Paz and the agricultural zone. This finding suggests that the hydraulic gradient has been inverted due to the cone of depression caused by intensive pumping in the agricultural area, thereby leading a flow coming from sea to inland. Based on the water-table levels discussed previously and contrasting them with the simulated hydraulic heads in Fig. 8a and the calculation of backward streamlines generated from each pumping well in Fig. 8b, an important flow coming from the southeastern region of the study area-recharge area of El Novillo mountain range (Fig. 1) - could be inferred. This flow has helped to slow down the advancement of the freshwater-saltwater interface between La Paz (towards the south of the city) and the agricultural lands, mitigating the saline intrusion. According to the model calculations, the groundwater residence time extends up to 1,500 years (Fig. 8b). Figure 8a also shows that some local flow lines are originating at the coastline and connecting with the city of La Paz, indicating pathways for saline-water intrusion towards the city. Coinciding with the interpretation of Figs. 7 and 8a,b, the inversion of the hydraulic gradient has caused the wells located in the agricultural area (towards the southwest of the city of La Paz) to extract groundwater with flow patterns come from both the coastline and the southern/ southeastern portion of the study area, promoting the mixing of freshwater with seawater and, therefore, increasing the salinity gradient in the aforementioned overexploited areas.

\section{Evolution of seawater intrusion in the last 20 years}

In order to evaluate the historical evolution of seawater intrusion, different isolines were generated for measured chloride concentrations $\left(250,500,750,1,000\right.$ and $\left.1,500 \mathrm{mg} \mathrm{L}^{-1}\right)$ in the study area from 1996 to 2015 (Fig. 9). The isolines were created by interpolation of point values through the inverse distance weighting method. The chloride data of the years 1996, 2001 and 2005 were provided by CONAGUA, chloride data of 2010 were obtained from CONAGUA and Rosales-Ramírez (2012), whereas the data of 2013 and 2015 were obtained from published (Tamez-Meléndez et al. 2016) and unpublished works performed by our team. The changing monitoring network of chloride concentration over time represents a limitation.

Of these isolines, the concentration of $250 \mathrm{mg} \mathrm{L}^{-1}$ is an essential value because it is the taste-based recommended concentration of chloride in drinking water established by the World Health Organization (WHO 2011), whereby beyond this level, the taste could usually be affected. The results indicate that from 1996 to 2010 , the green area $\left(<250 \mathrm{mg} \mathrm{L}^{-1}\right)$ tends to cover a wider area of La Paz, whereas the yellow isoline (between 750 and $1,000 \mathrm{mg} \mathrm{L}^{-1}$ ) tends to disappear in the city area, which suggests the retreat of the freshwater-saltwater interface in the city during this period. This finding agrees with the water-table increase in the wells located in the city (Fig. 7), which is caused 

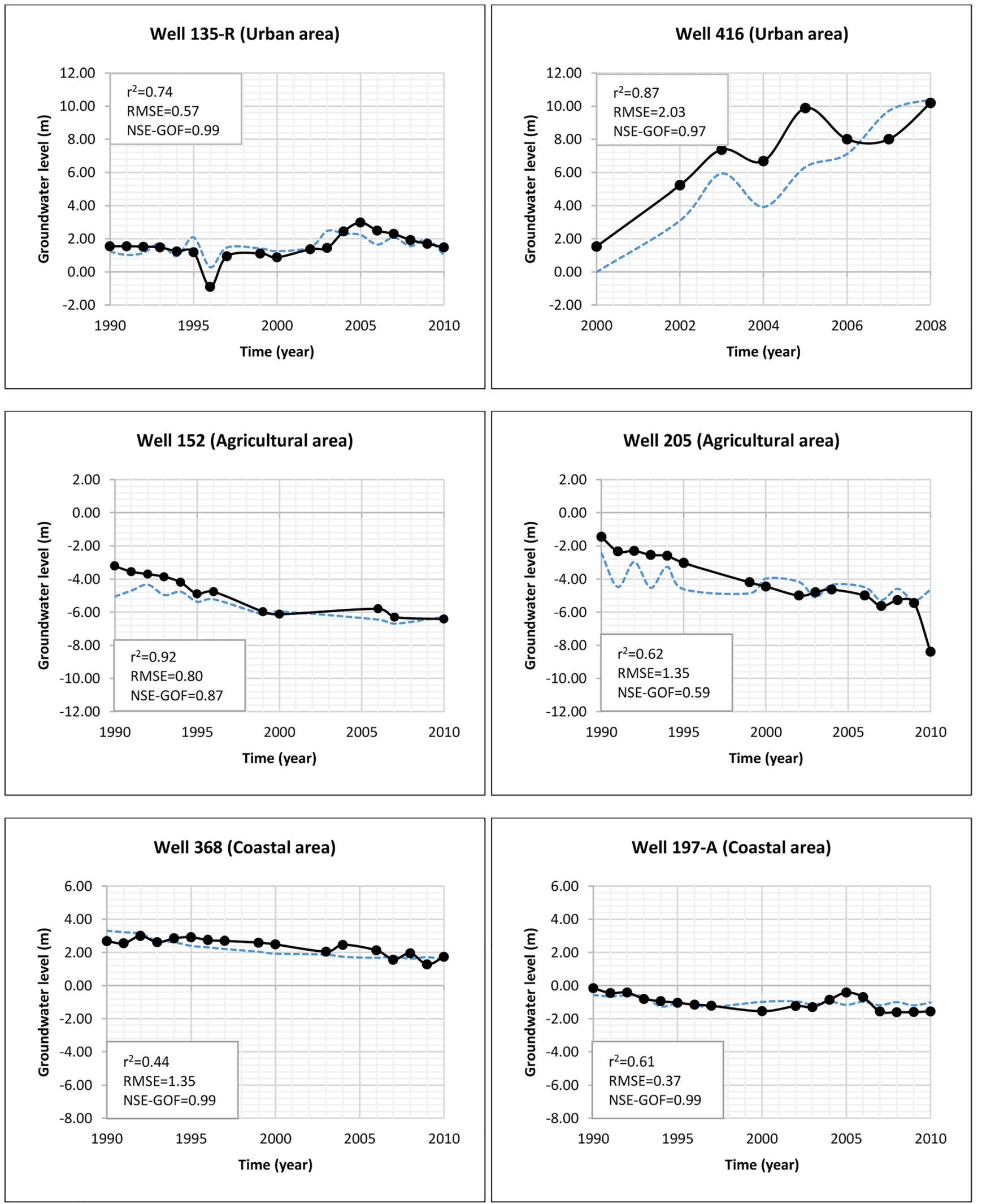

\section{Simulated $\longrightarrow$ Observed}

Fig. 7 Example of observed versus simulated groundwater levels in six selected wells applying the transient-state mode (the locations of the wells are shown in Fig. 2) 
Hydraulic head

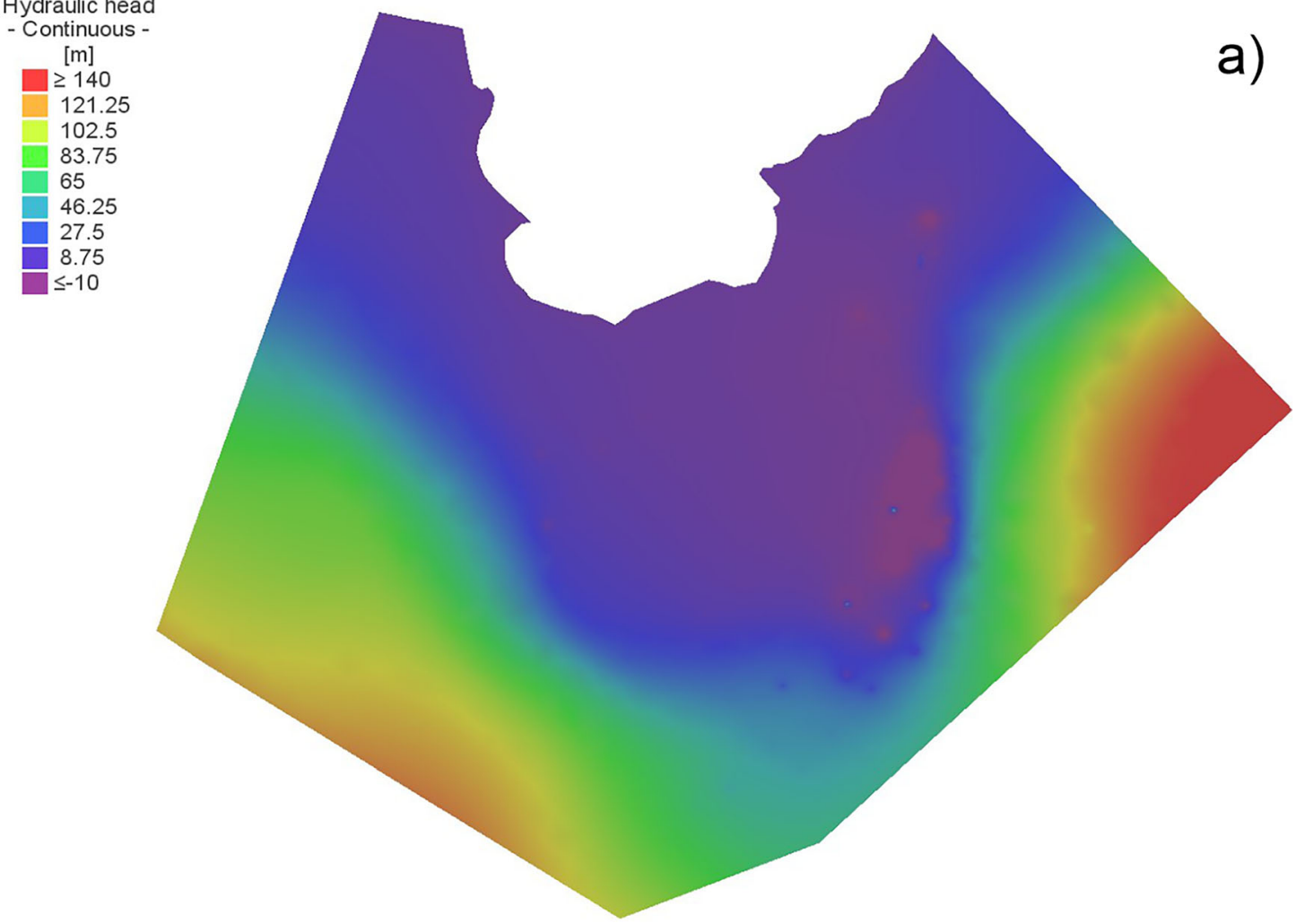

Travel time, Forward Streamlines (RW)

b)

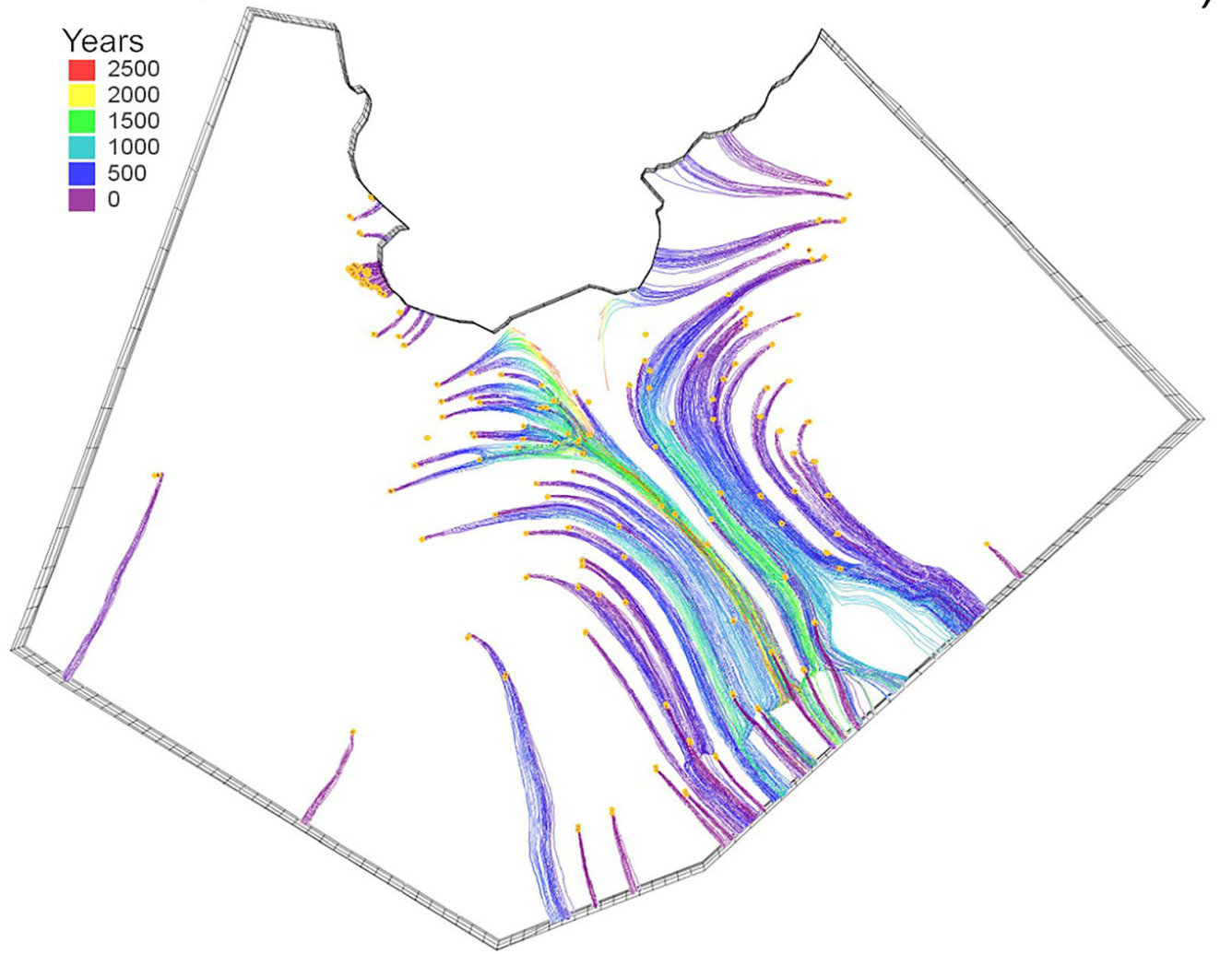

Fig. 8 a Simulated hydraulic head contours under steady-state conditions (slice 2); b Pathways of groundwater flow in the model domain 

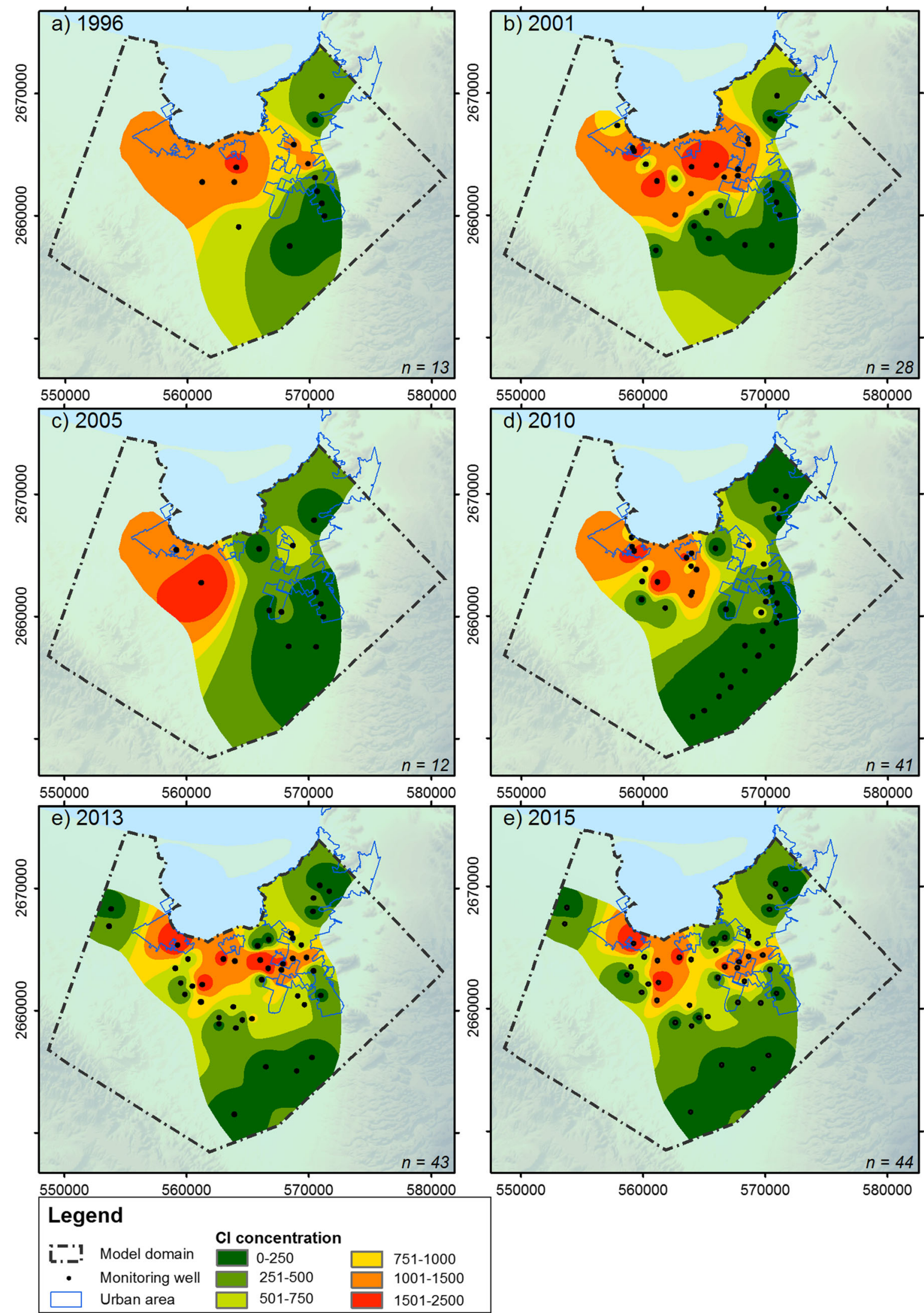

Fig. 9 a-e Interpolated distribution of measured chloride concentrations in 1996, 2001, 2005, 2010, 2013 and 2015. Note: $n$ denotes the number of wells used for each graph 
by artificial recharge coming from the water-supply-system leaks. Conversely, the red area $\left(>1,500 \mathrm{mg} \mathrm{L}^{-1}\right)$ shows an increasing trend in the center of the irrigation district from 1996 to 2001, which agrees with the descending water-table behavior of the wells located in the agricultural zone between the years 1995 and 2000. Thus, the enhancement of the $>1,500 \mathrm{mg} \mathrm{L}^{-1}$ isoline is undoubtedly due to the advancement of the freshwater-seawater interface as a consequence of the heavy groundwater extraction for irrigation purposes. Towards the south, the green area $\left(<250 \mathrm{mg} \mathrm{L}^{-1}\right)$ has progressed in the same period from Carrizal Valley towards the city of La Paz, oscillating between 6.5 and $8 \mathrm{~km}$ from the southern part of La Paz Bay. This isoline is mainly affected by two groundwater regional flows coming from the southern and southeastern parts of the aquifer, as previously described. In fact, this portion of the aquifer hosts the main production wells operated and exploited by the water utility of La Paz, who maintain the chloride concentrations below the taste-based limit mentioned by WHO, thereby satisfying the current water quality conditions for the public drinking water system. Otherwise, the isoline of $1,000 \mathrm{mg} \mathrm{L}^{-1}$ (concentration considered to be the limit between freshwater and brackish water) showed an advance in 2001 with regard to 1996 . However, this isoline has been retreating since 2001, showing a reduction of $2.1 \mathrm{~km}$ in the area near El Centenario and 5.3-6.5 km to the east of this community in 2015. Nevertheless, despite the overexploitation of this aquifer system, almost all the chloride isolines have retreated in 2015 in comparison with those in previous years, indicating that there was an efficient aquifer recharge in the last several years that diluted the groundwater.

One of the possible causes of the retreat of the seawater intrusion interphase can be attributed to the fact that in periods prior to those included in this work, some prolonged droughts were present since the 1950s in northern Mexico, as described in other works (CONAGUA 2014; Domínguez 2016). Those droughts could have caused water stress on the aquifer favoring the advancement of the seawater intrusion, and after this stress, the aquifer has been recovering to its natural condition. In addition, another variable to consider is that there was no proper regulation and control of groundwater resources in Mexico until 1992. In that year, the Law on National Waters of Mexico was created, and it was not until 1994 when a national registry of wells was implemented, where the number of wells, the different uses and the allocation of groundwater was reported for each aquifer (CONAGUA 2012; Pineda Pablos et al. 2014). This information leads to an additional consideration of droughts because excessive exploitation was carried out in the years before those considered in this study. However, these policies were enacted according to political and economic needs, sometimes obviating the aquifer overdraft (Hoogesteger 2018; Bhattacharjee et al. 2019). Another factor to take into account in the retreat of the freshwater-saltwater interface, is the occurrence of high precipitation events (hurricanes) in the south of Baja California, which increases precipitation significantly in a short time compared to the monthly average precipitation (Fig. 10). These extraordinary highprecipitation events have been demonstrated to decrease the risk of a water crisis in other semiarid regions of northern Mexico (Sisto et al. 2016). However, the contribution of hurricanes is not a piece of conclusive evidence for the aquifer recharge in this region, because the annual precipitation values do not show an increased tendency over time. Therefore, the contribution of the three mentioned factors (absence of extended drought periods, implementation of a national registry of wells and hurricanes) should be taken into account together as the probable explanation of the recent trend of the freshwater-seawater moving back to the coastline in the $\mathrm{La} \mathrm{Paz}$ aquifer, despite the continuous overextraction of groundwater.

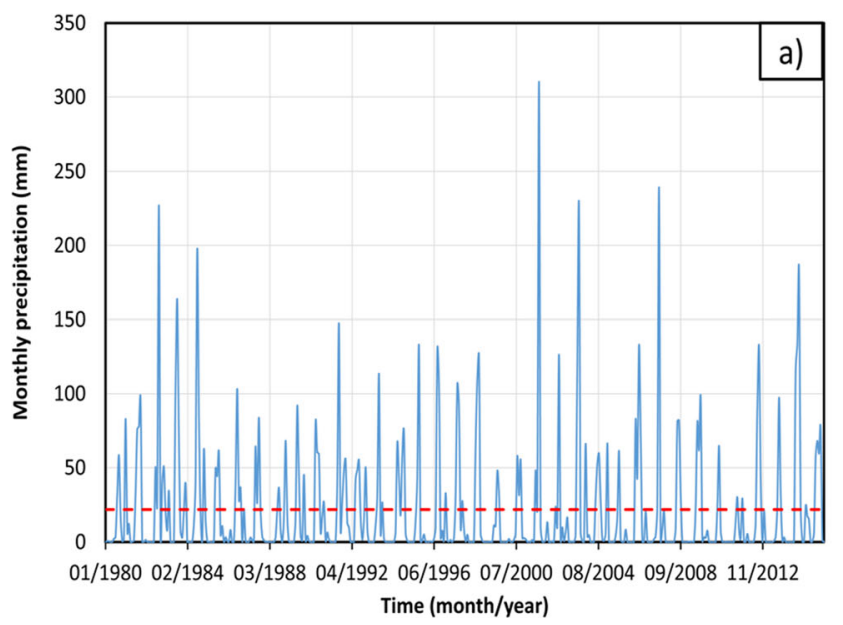

Fig. 10 a Monthly precipitation in $\mathrm{mm}$; $\mathbf{b}$ annual precipitation in $\mathrm{mm}$

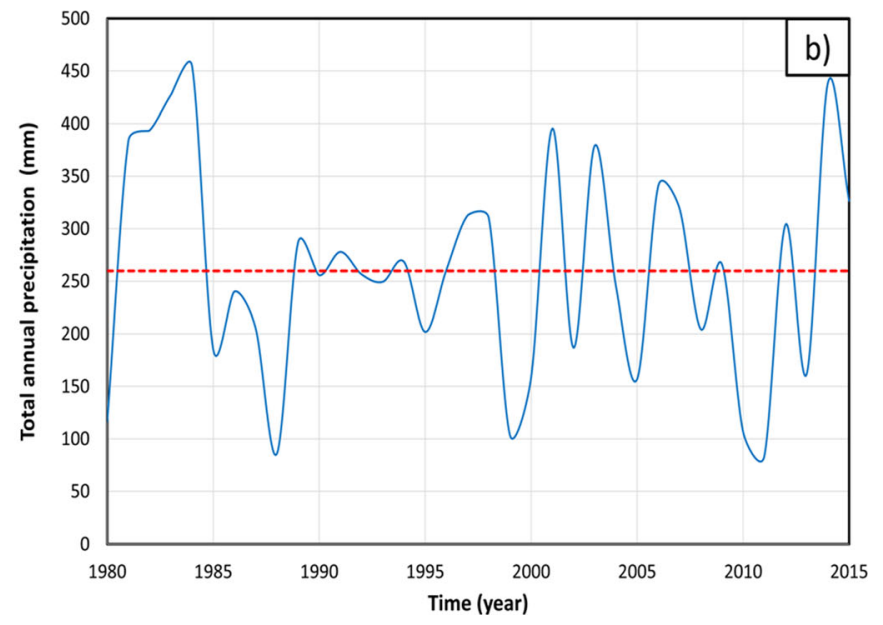




\section{Conclusions}

A tool for simulating, monitoring and managing saltwater intrusion was developed for a coastal area with a complex, heterogeneous aquifer system. This tool can provide support for decision-making for sustainable groundwater management in an arid coastal region with an intensified water demand due to increasing urbanization, tourism and agriculture. The results obtained from the 3D density-dependent flow model constrained by electromagnetic resistivity and geological data confirm that a freshwater-saltwater intrusion interface has been present in this area over the last two decades. Heavy groundwater extractions, mainly originating from the agricultural sector, produced a large cone of depression and hydraulic inversion of groundwater flow from the coastline to the central-eastern portion of the aquifer and, in turn, led to seawater intrusion along the coastline with an advancement of 6$8 \mathrm{~km}$. Reverse-particle-tracking calculations revealed that groundwater originated mainly from the recharge areas in the El Novillo mountain range located in the southeastern portion of the basin and provided freshwater to this overexploited area, counteracting the advancement of the freshwater-saltwater interface. Historical information on chloride concentrations revealed that salinization is not a process that advances in one direction, but rather consists of alternating advancement and retreat of the freshwater-seawater intrusion interface, according to changes in climate and/or regulatory rules. Future investigations should consider the forecasting of groundwater models considering uncertainty analysis.

Acknowledgements We would like to thank Daniel Merchán for his contribution to the development of the flow model.

Funding information This study was funded by the European Commission project WATERCLIMA-LAC Coastal Water Management, reference: EuropeAid/135857/DH/ACT/MULTI (RAL\&RCA). Additional resources were provided by the Water Science and Technology Chair of Tecnológico de Monterrey.

Open Access This article is distributed under the terms of the Creative Commons Attribution 4.0 International License (http:// creativecommons.org/licenses/by/4.0/), which permits unrestricted use, distribution, and reproduction in any medium, provided you give appropriate credit to the original author(s) and the source, provide a link to the Creative Commons license, and indicate if changes were made.

\section{References}

Alfarrah N, Walraevens K (2018) Groundwater overexploitation and seawater intrusion in coastal areas of arid and semi-arid regions. Water 10:143. https://doi.org/10.3390/w10020143

Aranda-Gómez JJ, Pérez-Venzor JA (1988) Estudio geológico de punta coyotes Baja California Sur [Geological study of Punta Coyotes, Baja California Sur]. Rev Univ Nal Autón México Inst Geol 7:1-21
Bhattacharjee S, Saha B, Saha B, Uddin MS, Panna CH, Bhattacharya P, Saha R (2019) Groundwater governance in Bangladesh: established practices and recent trends. Groundw Sustain Dev 8:69-81. https:// doi.org/10.1016/j.gsd.2018.02.006

Chai T, Draxler RR (2014) Root mean square error (RMSE) or mean absolute error (MAE)? Arguments against avoiding RMSE in the literature. Geosci Model Dev 7:1247-1250. https://doi.org/10.5194/ gmd-7-1247-2014

CIGSA (Consultores en Ingeniería Geofísica S.A. de C.V.) (2001) Estudio de caracterización y modelación de la intrusión marina en el acuífero de La Paz [Study to characterize and model saline intrusion of the aquifer of La Paz]. CIGSA, Silao, Mexico, $284 \mathrm{pp}$

CNA (Comisión Nacional del Agua) (2002) Determinación de la disecondsponibilidad de agua en el acuífero La Paz, Estado de Baja California Sur [Determination of water availability in the La Paz aquifer, State of Baja California Sur]. CNA, Mexico City

Comte J-C, Wilson C, Ofterdinger U, González-Quirós A (2017) Effect of volcanic dykes on coastal groundwater flow and saltwater intrusion: a field-scale multiphysics approach and parameter evaluation. Water Resour Res 53:2171-2198. https://doi.org/10.1002/ 2016WR019480

CONAGUA (Comisión Nacional del Agua) (2010) Situación actual y posibles escenarios de intrusión salina en el acuífero La Paz, Baja California Sur y su aprovechamiento como fuente de desalación para abastecimiento de agua potable [Current situation and possible scenarios of saline intrusion in the La Paz aquifer, Baja California Sur, and its use as desalinization source for drinking water purpose]. CONAGUA, Mexico City

CONAGUA (Comisión Nacional del Agua) (2012) Memoria documental: Registro Público de derechos de Agua [Documentary memory: public registry of water rights]. CONAGUA, Mexico City

CONAGUA (Comision Nacional del Agua) (2014) Programa de medidas preventivas y de mitigación de la sequía: Consejo de Cuenca Baja California Sur [Program of preventive drought measures and mitigation: Council of Baja California Sur Basin]. CONAGUA, Mexico City

Cruz-Falcón A (2007) Caracterización y diagnóstico del acuífero de La Paz, B.C.S. mediante estudios geofísicos y geohidrológicos [Characterization and diagnosis of the La Paz aquifer, B.C.S. using geophysical and geohydrological studies]. Instituto Politécnico Nacional, Mexico City

Cruz-Falcón A, Vázquez-González R, Ramírez-Hernández J, SalinasGonzález F, Nava-Sánchez E, Troyo-Diéguez E (2010) Depth estimation to crystalline basement in the valley of La Paz, Baja California Sur, Mexico. Geofis Int 49:213-224

Cruz Falcón A, Ramírez-Hernández J, Vázquez-González R, NavaSánchez EH, Troyo-Diéguez E, Fraga-Palomino HC (2013) Estimación de la Recarga y balance Hidrológico del Acuífero de la Paz, BCS, México [Estimation of the recharge and hydrological balance of the aquifer of Peace, BCS, Mexico]. Univ Cienc 29:87100

Cruz Falcón A, Troyo Diéguez E, Murillo Jiménez JM, García Hernández JL, Murillo Amador B (2017) Familias de agua subterránea y distribución de sólidos totales disueltos en el acuífero de La Paz Baja California Sur, México [Groundwater families and distribution of total dissolved solids in the La Paz aquifer Baja California Sur, Mexico]. Terra Latinoam 36:39-48. https://doi.org/10.28940/terra. v36il.316

Danielsen JE, Auken E, Jørgensen F, Søndergaard V, Sørensen KI (2003) The application of the transient electromagnetic method in hydrogeophysical surveys. J Appl Geophys 53:181-198. https:// doi.org/10.1016/j.jappgeo.2003.08.004

De Filippis G, Foglia L, Giudici M, Mehl S, Margiotta S, Negri SL (2016) Seawater intrusion in karstic, coastal aquifers: current challenges and future scenarios in the Taranto area (southern Italy). Sci Total 
Environ 573:1340-1351. https://doi.org/10.1016/j.scitotenv.2016. 07.005

Delleur JW (2016) Elementary groundwater flow and transport processes. In: The handbook of groundwater engineering, 3rd edn. CRC, Boca Raton. FL

Diersch H-J (1988) Finite element modelling of recirculating densitydriven saltwater intrusion processes in groundwater. Adv Water Resour 11:25-43. https://doi.org/10.1016/0309-1708(88)90019-X

Diersch H-JG (2014) FEFLOW: finite element modeling of flow, mass and heat transport in porous and fractured media. Springer, Heidelberg, Germany

Domínguez J (2016) Revisión histórica de las sequías en México: de la explicación divina a la incorporación de la ciencia [Historic revision of droughts in Mexico: the divine explanation of science]. Tecnol Ciencias Agua 7:77-93

Flores C, Romo JM, Vega M (2013) On the estimation of the maximum depth of investigation of transient electromagnetic soundings: the case of the Vizcaino Transect, Mexico. Geofis Int 52:159-172. https://doi.org/10.1016/S0016-7169(13)71470-3

Francés AP, Ramalho EC, Fernandes J, Groen M, Hugman R, Khalil MA, De Plaen J, Santos FA (2015) Contributions of hydrogeophysics to the hydrogeological conceptual model of the Albufeira-Ribeira de Quarteira coastal aquifer in Algarve, Portugal. Hydrogeol J 23: 1553-1572. https://doi.org/10.1007/s10040-015-1282-x

Gopinath S, Srinivasamoorthy K, Saravanan K, Prakash R (2018) Discriminating groundwater salinization processes in coastal aquifers of southeastern India: geophysical, hydrogeochemical and numerical modeling approach. Environ Dev Sustain. https://doi.org/ 10.1007/s10668-018-0143-x

Graham MT, MacAllister DJ, Vinogradov J, Jackson MD, Butler AP (2018) Self-potential as a predictor of seawater intrusion in coastal groundwater boreholes. Water Resour Res 54:6055-6071. https:// doi.org/10.1029/2018WR022972

Hausback BP (1984) Cenozoic volcanic and tectonic evolution of Baja California Sur, Mexico. In: Frizzell VAJ (ed) Geology of the Baja California peninsula. Pacific Section, Society of Economic Paleontologist and Mineralogists, Bakersfield, CA, pp 219-236

Herckenrath D, Langevin CD, Doherty J (2011) Predictive uncertainty analysis of a saltwater intrusion model using null-space Monte Carlo. Water Resour Res 47:1-16. https://doi.org/10.1029/ 2010WR009342

Hoogesteger J (2018) The ostrich politics of groundwater development and neoliberal regulation in Mexico. Water Altern 11:552-571

Hugman R, Stigter TY, Monteiro JP, Costa L, Nunes LM (2015) Modeling the spatial and temporal distribution of coastal groundwater discharge for different water use scenarios under epistemic uncertainty: case study in South Portugal. Environ Earth Sci 73:26572669. https://doi.org/10.1007/s12665-014-3709-4

INEGI (Instituto Nacional de Estadística Geografia e Informática) (2013) Continuo de Elevaciones Mexicano 3.0 (CEM 3.0) [Continuity of Mexican elevations 3.0]. https://www.inegi.org.mx/app/geo2/ elevacionesmex/. Accessed August 2019

INEGI (Instituto Nacional de Estadística Geografía e Informática) (2017) Anuario Estadístico y Geográfico de Baja California Sur 2017 [Statistical and geographic yearbook of Baja California Sur 2017]. INEGI, Aguascalientes, Mexico

Kalisperi D, Kouli M, Vallianatos F, Soupios P, Kershaw S, LydakisSimantiris N (2018) A transient ElectroMagnetic (TEM) method survey in north-central coast of Crete, Greece: evidence of seawater intrusion. Geosciences 8:107. https://doi.org/10.3390/ geosciences 8040107

Kazakis N, Pavlou A, Vargemezis G, Voudouris KS, Soulios G, Pliakas F, Tsokas G (2016) Seawater intrusion mapping using electrical resistivity tomography and hydrochemical data: an application in the coastal area of eastern Thermaikos Gulf. Greece Sci Total Environ 543:373-387. https://doi.org/10.1016/j.scitotenv.2015.11.041
Khayyun T (2018) Simulation of groundwater flow and migration of the radioactive Cobalt-60 from LAMA nuclear facility-Iraq. Water 10: 176. https://doi.org/10.3390/w10020176

Kolditz O, Ratke R, Diersch H-JG, Zielke W (1998) Coupled groundwater flow and transport: 1 . verification of variable density flow and transport models. Adv Water Resour 21:27-46. https://doi.org/10. 1016/S0309-1708(96)00034-6

Kourgialas NN, Dokou Z, Karatzas GP, Panagopoulos G, Soupios P, Vafidis A, Manoutsoglou E, Schafmeister M (2016) Saltwater intrusion in an irrigated agricultural area: combining density-dependent modeling and geophysical methods. Environ Earth Sci 75:15. https://doi.org/10.1007/s12665-015-4856-y

de los Monteros López-Espinosa R (2002) Evaluating ecotourism in natural protected areas of La Paz Bay, Baja California Sur, México: ecotourism or nature-based tourism? Biodivers Conserv 11:15391550. https://doi.org/10.1023/A:1016887417263

Mahlknecht J, Merchán D, Rosner M, Meixner A, Ledesma-Ruiz R (2017) Assessing seawater intrusion in an arid coastal aquifer under high anthropogenic influence using major constituents, $\mathrm{Sr}$ and $\mathrm{B}$ isotopes in groundwater. Sci Total Environ. https://doi.org/10. 1016/j.scitotenv.2017.02.137

McCloskey T, Bianchette T, Liu K (2015) Geological and sedimentological evidence of a large tsunami occurring $\sim 1100$ year BP from a small coastal lake along the Bay of La Paz in Baja California Sur, Mexico. J Mar Sci Eng 3:1544-1567. https://doi.org/10.3390/ jmse3041544

Meyer R, Engesgaard P, Sonnenborg TO (2019) Origin and dynamics of saltwater intrusion in a regional aquifer: combining 3D saltwater modeling with geophysical and geochemical data. Water Resour Res 55:1792-1813. https://doi.org/10.1029/2018WR023624

Monzalvo M (2010) Simulación hidrodinámica del acuífero de La Paz y su aprovechamiento como fuente de desalación [Hydrodinamic simulation of La Paz aquifer and its use as source for desalinization]. MSc Thesis, Univ. Nac. Autónoma México, Mexico City

Moriasi DN, Arnold JG, Van Liew MW, Bingner RL, Harmel RD, Veith TL (2007) Model evaluation guidelines for systematic quantification of accuracy in watershed simulations. Trans ASABE 50:885-900. https://doi.org/10.13031/2013.23153

Pineda Pablos N, Moreno Váquez JL, Salazar Adams A, Lutz Ley AN (2014) Derechos de agua y gestión por cuencas en México. El Caso del Río Sonora [Water rights and watershed management in Mexico: the case of Sonora River]. Espiral 21:191-225

Piñeiro G, Perelman S, Guerschman JP, Paruelo JM (2008) How to evaluate models: observed vs. predicted or predicted vs. observed? Ecol Model 216:316-322. https://doi.org/10.1016/j.ecolmodel.2008.05. 006

Ritter A, Muñoz-Carpena R (2013) Performance evaluation of hydrological models: statistical significance for reducing subjectivity in goodness-of-fit assessments. J Hydrol 480:33-45. https://doi.org/ 10.1016/j.jhydrol.2012.12.004

Rodríguez N, Silveira R (2017) Implementing data-dependent triangulations with higher order Delaunay triangulations. ISPRS Int J GeoInform 6:390. https://doi.org/10.3390/ijgi6120390

Rosales-Ramírez TY (2012) Reconocimiento químico e isotópico del acuífero costero de La Paz, B.C.S: Evaluación de una posible intrusión marina [Chemical and isotopic signatures of the coastal aquifer of La Paz, B.C.S.: evaluation of a posible saltwater intrusion]. Centro de Investigación Científica y de Educación Superior de Ensenada, Baja California

SAPA (Organismo Operador Municipal del Sistema de Agua Potable Alcantarillado y Saneamiento) (2015) Información general: indicadores La Paz [General Information: indicators of La Paz]. http://201.144.52.130/sapa/Enlaces/Infgral.htm. Accessed Aug 2019 
Sepúlveda N, Doherty J (2015) Uncertainty analysis of a groundwater flow model in east-central Florida. Groundwater 53:464-474. https://doi.org/10.1111/gwat.12232

SGM (Servicio Geológico Mexicano) (1995) Informe de definición del prospecto de asignación minera de San Juan, Municipio de La Paz, Estado de Baja California Sur [Report about prospect definition of the San Juan mining allocation]. SGM, Hidalgo, Mexico

Siaka M, Dokou Z, Karatzas GP (2017) Management of the saltwater intrusion phenomenon in the alluvial aquifer of Katapola, Amorgos, Greece. Water Sci Technol Water Supply 18:936-949. https://doi.org/10.2166/ws.2017.160

Sisto NP, Ramírez AI, Aguilar-Barajas I, Magaña-Rueda V (2016) Climate threats, water supply vulnerability and the risk of a water crisis in the Monterrey metropolitan area (northeastern Mexico). Phys Chem Earth, Parts A/B/C 91:2-9. https://doi.org/10.1016/j. pce.2015.08.015

Soupios P, Nektarios K, Zoi D, George K, George P, Antonis V, Emmanuil M (2015) Modeling saltwater intrusion at an agricultural coastal area using geophysical methods and the FEFLOW model. In: Lollino G, Arattano M, Rinaldi M et al (eds) Engineering geology for society and territory, vol 3. Springer, Cham, Switzerland, pp 249-252

Soupios PM, Kalisperi D, Kanta A, Kouli M, Barsukov P, Vallianatos F (2010) Coastal aquifer assessment based on geological and geophysical survey, northwestern Crete, Greece. Environ Earth Sci 61:6377. https://doi.org/10.1007/s12665-009-0320-1

Tamez-Meléndez C, Hernández-Antonio A, Gaona-Zanella PC, OrnelasSoto N, Mahlknecht J (2016) Isotope signatures and hydrochemistry as tools in assessing groundwater occurrence and dynamics in a coastal arid aquifer. Environ Earth Sci 75. https://doi.org/10.1007/ s12665-016-5617-2
Tezkan B (1999) A review of environmental applications of quasistationary electromagnetic techniques. Surv Geophys 20:279-308. https://doi.org/10.1023/A:1006669218545

Torres-Martínez JA (2017) Modelación matemática de flujo subterráneo e intrusión salina aplicada al acuífero de La Paz, Baja California Sur [Mathematical modelo of groundwater flow and saltwater intrusion applied to La Paz aquifer, Baja California Sur]. Tecnologico de Monterrey, Monterrey, Mexico

Torres-Martínez JA, Mahlknecht J, Hernández-Antonio A, Mora A (2017) Origin of the salinity in the coastal aquifer of La Paz, Mexico. Procedia Earth Planet Sci 17:520-523. https://doi.org/10. 1016/j.proeps.2016.12.131

Vaze J, Jordan P, Beecham R, Frost A, Summerell G (2011) Guidelines for rainfall-runoff modelling towards best practice model application. eWater, Bruce, ACT, Australia

Weatherill NP (1992) Delaunay triangulation in computational fluid dynamics. Comput Math with Appl 24:129-150. https://doi.org/10. 1016/0898-1221(92)90045-J

WHO (World Health Organization) (2011) Guidelines for drinking-water quality. WHO, Geneva

Zarif F, Slater L, Mabrouk M, Youssef A, Al-Temamy A, Mousa S, Farag K, Robinson J (2018) Groundwater resources evaluation in calcareous limestone using geoelectrical and VLF-EM surveys (El Salloum Basin, Egypt). Hydrogeol J 26:1169-1185. https://doi.org/10.1007/ s10040-017-1710-1

Ziadi A, Hariga NT, Tarhouni J (2017) Use of time-domain electromagnetic (TDEM) method to investigate seawater intrusion in the Lebna coastal aquifer of eastern Cap Bon, Tunisia. Arab J Geosci 10:492. https://doi.org/10.1007/s12517-017-3265-9 